\title{
Production and Quality of Okra Fruits Submitted to Doses and Types of Biofertilizers
}

\author{
Jonnathan Richeds da Silva Sales ${ }^{1}$, Geocleber Gomes de Sousa ${ }^{1}$, Fabio Cavalcante ${ }^{1}$, \\ João Gutemberg Leite Moraes ${ }^{1}$, Kelly Nascimento Leite ${ }^{2} \&$ Thales Vinicius de Araujo Viana ${ }^{3}$ \\ ${ }^{1}$ Institute of Rural Development, University of International Integration of Afro-Brazilian Lusophony, Redenção, \\ Ceará, Brazil \\ ${ }^{2}$ Federal University of Acre, Cruzeiro do Sul, Acre, Brazil \\ ${ }^{3}$ Federal University of Ceará, Fortaleza, Ceará, Brazil \\ Correspondence: Jonnathan Richeds da Silva Sales, Institute of Rural Development, University of International \\ Integration of Afro-Brazilian Lusophony, Redenção, Ceará, Brazil. E-mail: jonnathanagro@gmail.com
}

Received: December 18, 2018

Accepted: January 27, 2019 Online Published: March 15, 2019

doi:10.5539/jas.v11n4p507

URL: https://doi.org/10.5539/jas.v11n4p507

\begin{abstract}
This study aimed to evaluate the yield and the quality of the fruits of two okra cultivars (Abelmoschus esculentus), due to the varying doses and types of biofertilizers. The experiment was conducted the period September to December of 2017, at the experimental Piroás Farm, in the city of Redenção-CE, Brazil. The experimental design used was entirely randomized, in factorial design $5 \times 2 \times 2$, referring to the five doses of the biofertilizer $\left(0,0.5,1,1.5\right.$ and $2.0 \mathrm{~L} \mathrm{plant}^{-1}$ week $\left.^{-1}\right)$, versus two types of liquid biofertilizers (bovine and caprine under aerobic fermentation) and two okra cultivars: Santa Cruz 47 and Clemson Spineless. The number of the fruits per plant, the average mass of the fruits, yield, the length and diameter of the fruit and peel thickness of the okra fruit, were increased according to the increase on the biofertilizers doses. The cultivar "Santa Cruz 47" presented higher values in the length of the fruit, whereas the cultivar "Clemson Americano 80" was superior in the variables "average fruit mass" and "diameter of the fruits".
\end{abstract}

Keywords: Abelmoschus esculentus, organic input, productivity

\section{Introduction}

The okra (Abelmoschus esculentus), belonging to the family Malvaceae, is an annual shrub-bearing plant, native to the African continent, whose fruits are rich in carbohydrates, proteins, vitamins, minerals and unsaturated fats (Filgueira, 2012). It is especially cultivated by family farmers, since it presents a fast vegetative cycle, resistance to pests and diseases, and low productivity cost, being widely planted in Brazil. According to data from the Agricultural Census, Brazil produced, in 2017, about 128,460 tonnes of okra, the Northeast being the second largest producer with 32,337 tonnes, corresponding to $25.1 \%$ of the national production (IBGE, 2018).

It should be emphasized that the cultivation management used by the farmers for this culture, employ low levels of technology, which limits the productivity potential of this culture, being necessary to adopt practices that promote gains in yield (Oliveira et al., 2013). An accessible alternative for the producers that has been quiet studied is the organic fertilization through biofertilizers.

The biofertilizers are liquid components, originated from the fermentation of organic compounds and water, under aerobic and anaerobic conditions, (Penteado, 2007) and because they have essential elements to the culture (Viana et al., 2013). According to Filgueira (2012), vegetables respond well to this type of fertilization, both in productivity and quality of the products obtained, with cattle manure being the organic source most used by the vegetable farmers.

This organic fertilizer is of low cost and has been presenting satisfactory results, various studies confirm that the use of these inputs promote an increase in the vegetables yield. Oliveira et al. (2013), researching the okra yield fertilized with manure and bovine biofertilizer, it was found an increase in yield, when compared to the control treatment. Oliveira et al. (2014), a research on the yield of maxixe due to the doses of manure and bovine biofertilizer, verified that the yield of this culture has significantly responded to the use of bovine manure, associated with bovine biofertilizer, coming to a total yield of $13.8 \mathrm{tha}^{-1}$ on the $31.0 \mathrm{t} \mathrm{ha}^{-1}$ dose of bovine manure. 
Santos et al. (2014a), investigating the quality of the melon plant fruits in the doses of biofertilizers, it was found that the transverse diameter of the fruits and the thickness of the pulp raised with the use of bovine biofertilizer.

This form of fertilization contributes in a decisive way to the improvement of soil characteristics, enabling to reduce the cost of crop production, since the input that more drives up the cost of production of okra is mineral fertilizer used in planting and cover (Oliveira et al., 2014).

Based on the above, the main aim for the study was to evaluate the yield and the quality of the fruits of two okra cultivars due to the different doses and types of liquid biofertilizers.

\section{Method}

\subsection{Characteristics of the Experimental Area}

The experiment was carried out from September to December 2017, the study was conducted at Piroás Farm experimental area in the University of International Integration of Afro-Brazilian Lusophony, located in Redenção-CE, Brazil under geographical coordinates: $04^{\circ} 14^{\prime} 53^{\prime \prime} \mathrm{S}, 38^{\circ} 45^{\prime} 10^{\prime \prime} \mathrm{W}$ and average altitude of $340 \mathrm{~m}$. According to the Köppen-Geiger Climate Classification (Köppen, 1918), the region climate is classified as Aw', in other words, rainy tropical, very warm, with predominance of rain during the summer and fall seasons.

\subsection{Management of the Soil and Plant on the Experiment}

The material used as substrate came from the Argissolo Vermelho Amarelo EMBRAPA (2018). For evaluation of the soil conditions, a sample was collected before the treatment started and it was sent to the Soil and Water Lab of the Departamento de Ciências do Solo/UFC, whose results of chemical analysis can be visualized on Table 1 .

Table 1. Soil chemical attributes used in okra cultivation

\begin{tabular}{|c|c|c|c|c|c|c|c|c|c|c|c|}
\hline \multicolumn{12}{|c|}{ Chemical Characteristics } \\
\hline OM & $\mathrm{N}$ & $\mathrm{Ca}^{2+}$ & $\mathrm{K}^{+}$ & $\mathrm{Mg}^{2+}$ & $\mathrm{Na}^{+}$ & $\mathrm{H}^{+}+\mathrm{Al}^{3+}$ & $\mathrm{Al}$ & SB & $\mathrm{P}$ & CTC & $\mathrm{V}$ \\
\hline \multicolumn{2}{|c|}{------ $\mathrm{g} \mathrm{kg}^{-1}$} & \multicolumn{7}{|c|}{ - } & $\mathrm{mg} \mathrm{kg}^{-1}$ & \multicolumn{2}{|c|}{-------- \% ----- } \\
\hline 5.28 & 0.31 & 2.3 & 0.27 & 2.7 & 0.05 & 0.99 & 0.05 & 5.3 & 56 & 6.7 & 84 \\
\hline
\end{tabular}

Note. OM: Organic Matter; BS: Basis Sum $\left(\mathrm{Ca}^{2}+\mathrm{Mg}^{2+}+\mathrm{Na}^{+}+\mathrm{K}+\right)$; CEC: Cations Exchange Capacity- $\left[\mathrm{Ca}^{2}+\right.$ $\left.\mathrm{Mg}^{2+}+\mathrm{Na}^{+}+\mathrm{K}^{+}+\left(\mathrm{H}^{+}+\mathrm{Al}^{3+}\right)\right]$; V: Basis Saturation- $\left(\mathrm{Ca}^{2}+\mathrm{Mg}^{2+}+\mathrm{Na}^{+}+\mathrm{K}^{+} / \mathrm{CTC}\right) \times 100$.

The okra seeds were seeded in sowings and 15 days after the establishment of seedlings were transplanted to plastic pots with 25 liter substrate capacity, in Full Sun conditions. It was installed a drip watering system, and the watering was done in daily frequency, according to the needs of each plant.

\subsection{Experimental Delineation and Treatments Used}

The experimental delineation was randomized, in factorial design $5 \times 2 \times 2$, with five repetitions, coming to one hundred experimental units. The treatments were according to five doses of biofertilizers $(0,0.5,1,1.5$ and $2.0 \mathrm{~L}$ plant $^{-1}$ week ${ }^{-1}$ two types of liquid biofertilizers (bovine and caprine) and two okra cultivars (Santa Cruz 47 and Clemson Spineless 80).

The biofertilizers, using fresh manure of bovine and caprine origin, were prepared separately through aerobic fermentation with addition of water in proportion of 50\% (volume of fresh manure/volume of water), for 30 days, in 200 liters recipients (Sousa et al., 2013). Following that, a mixture of the ingredients took place, using adapted aerator.

The level of mineral elements (Table 2), in the chemical composition of the liquid biofertilizers dry matter, were analyzed according to methodology suggested by Malavolta et al. (1997).

Table 2. Composition of macro and micronutrients essentials in the dry matter of biofertilizers (BIO) bovine (B1) and caprine (B2)

\begin{tabular}{|c|c|c|c|c|c|c|c|c|c|}
\hline Biofertilizers & $\mathrm{N}$ & $\mathrm{P}$ & $\mathrm{K}$ & $\mathrm{Ca}$ & $\mathrm{Mg}$ & $\mathrm{Fe}$ & $\mathrm{Cu}$ & $\mathrm{Zn}$ & $\mathrm{Mn}$ \\
\hline & \multicolumn{5}{|c|}{ 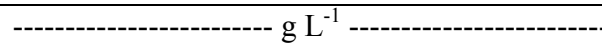 } & \multicolumn{4}{|c|}{ |---------------- mg L'-1 ---------------- } \\
\hline Bovine & 2.73 & 3.1 & 2.3 & 3.1 & 0.6 & 42.6 & 0.2 & 6.1 & 6.1 \\
\hline Caprine & 0.26 & 0.26 & 4.2 & 4 & 0.9 & 82.6 & 0.1 & 3.8 & 0.8 \\
\hline
\end{tabular}




\subsection{Production Parameters and the Quality of the Fruits Evaluated}

The harvest the okra fruits was done manually every three days for ten weeks. After harvesting, the fruits were packed in plastic bags, identified and taken to Plant Physiology Laboratory-UNILAB, where the evaluations were performed. The variables analyzed were the following: number of fruits per plant (NFP); average fruit mass (MMF), obtained by dividing the fresh fruit mass from each plot the number of fruits of the respective portion, with the result expressed in grams $(\mathrm{g})$; length of fruits $(\mathrm{CF})$, measured with a ruler graduated in centimeters $(\mathrm{cm})$; fruit diameter (DF), measured with the aid of digital caliper in the median area of the fruit, with the result expressed in millimeters (mm); fruit peel thickness (PT), using digital caliper, with results in millimeters (mm); and productivity (PROD), considering the yield gives usable area of each plot by the population density of plants, expressed in $\mathrm{t} / \mathrm{ha}^{-1}$.

\subsection{Statistical Analysis}

The observed data were submitted to analysis of variance. Subsequently, when significant by the F Test, the data referring to the okra cultivars and types of biofertilizers were submitted to Means Test by Tukey Test in level of $1 \%$ and $5 \%$ of probability. However, the referring data to the doses of biofertilizers were submitted to regression analysis seeking to adjust equations with biological meanings. In the regression analysis, the equations that best adjusts to the chosen data based on the significance of the coefficient of regression to $(p \leq 0.10)$ and $(p \leq 0.05)$, of probability by the $\mathrm{F}$ test and in the highest coefficient of determination $\left(\mathrm{R}^{2}\right)$.

\section{Results}

The analysis of variance shows that there was significant interaction between doses, types of biofertilizers and okra cultivars to variables number of fruits per plant variables (NFP) and fruit peel thickness (PT). The average mass fruit (AFM) and fruit diameter (FD), were statistically influenced by the effect of the doses of biofertilizer and by the cultivars. However, the fruit length variable (FL) was significantly influenced from the interaction between the doses versus types of biofertilizers, and the cultivars factor, while the yield (Y) was influenced by the effect of biofertilizers doses.

It was found that the increase on the biofertilizer doses raised the number of fruits per okra plant of Santa Cruz 47 cultivar (Image 1A), where, the linear model was the one that best adjusted with the values of 6.2 and 4.5 fruits per okra plant, regarding the dose of $2.0 \mathrm{~L}_{\text {bovine and caprine biofertilizer plant }}{ }^{-1}$ week $^{-1}$, respectively.

On Image 1B, the increase on the doses of biofertilizers caused a raise on the number of fruits per okra plant from the Clemson Spineless 80 cultivar, obtaining maximum values of $25.6 \%$ and $42.1 \%$ according to the dose of $2.0 \mathrm{~L} \mathrm{plant}^{-1}$ week ${ }^{-1}$, compared to the witness dose $\left(0.0\right.$ plant $^{-1}$ week $\left.^{-1}\right)$, to the treatments with bovine and caprine biofertilizers, respectively.
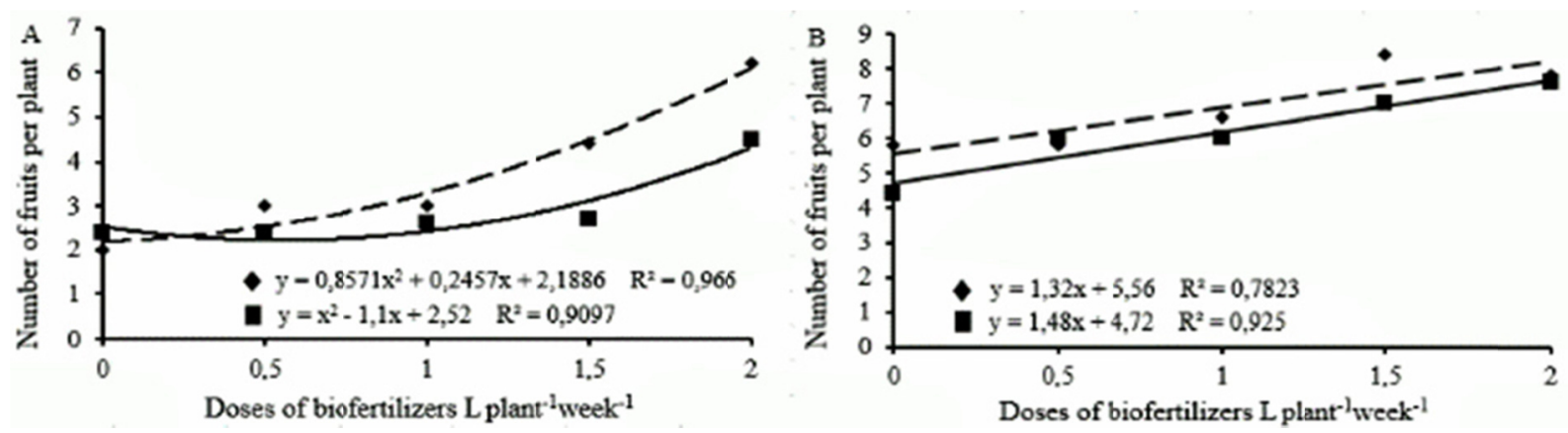

Figure 1. The number of fruits per okra plant, Santa Cruz 47 cultivar (A) and Clemson Spineless cultivar (B), submitted to different doses of bovine $(\bullet)$ and caprine $(\boldsymbol{\bullet})$ biofertilizer

The average okra fruit mass was linearly raised according to the increase on the dose of biofertilizer (Image 2A), with maximum average of $29.9 \mathrm{~g}$ equal to a $2.0 \mathrm{~L}_{\text {dose }}$ plant $^{-1}$ week $^{-1}$, obtaining a maximum increase of $28.86 \%$ compared to the control treatment $\left(0.0 \mathrm{~L} \mathrm{plant}^{-1} \mathrm{week}^{-1}\right)$.

On the Image 2B, the Clemson Spineless 80 cultivar, presented results superior to $12.8 \%$ on average fruit mass compared to Santa Cruz cultivar. 

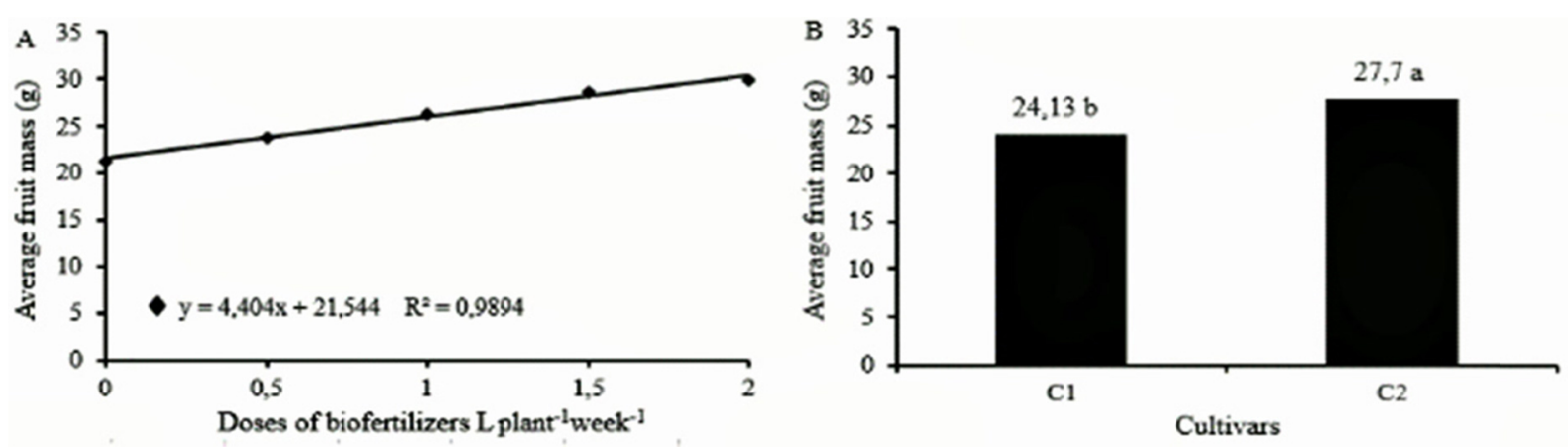

Figure 2. Average okra fruit mass due to the different doses of biofertilizer (A) and two commercial cultivars (B) Santa Cruz 47 (C1) and Clemson Spineless 80 (C2)

The yield of the okra was significantly influenced by the doses of biofertilizer, where the dose equivalent to 2.0 $\mathrm{L}$ plant ${ }^{-1}$ week $^{-1}$ of biofertilizer was responsible for the okra fruit yield of $30.005 \mathrm{t} \mathrm{ha}^{-1}$ (Figura 3), obtaining a maximum increase of $28.1 \%$ compared to the control treatment $\left(0.0 \mathrm{~L} \mathrm{plant}^{-1}\right.$ week $\left.^{-1}\right)$.

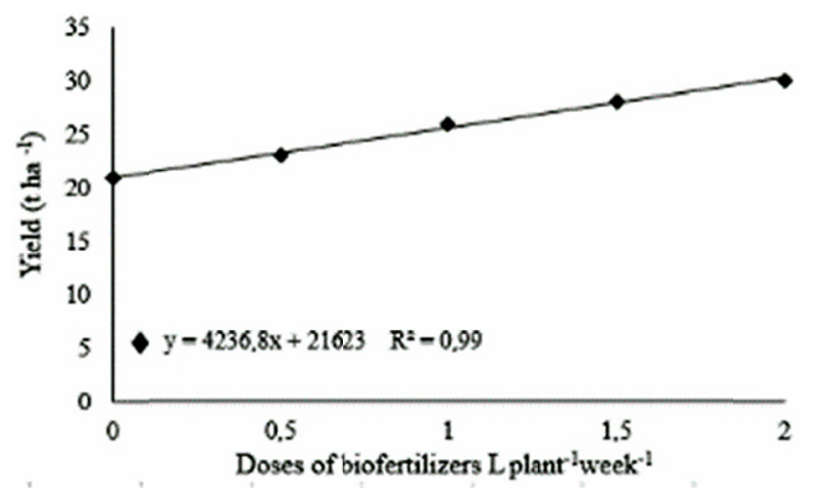

Figure 3. Okra yield due to the different doses of biofertilizers

The different doses and types of biofertilizers applied to the soil in pot conditions on the cultivation of okra have positively influenced the length of the fruit (Image 4A), where the linear model was the one which has adjusted best to the treatment with bovine biofertilizers, with unitary increase of $1.07 \mathrm{~cm}$ per dose, obtaining gain of $15.2 \%$ equivalent to the dose of $2.0 \mathrm{~L} \mathrm{plant}^{-1}$ week $^{-1}$ compared to the witness dose $\left(0.0 \mathrm{~L} \mathrm{plant}^{-1}\right.$ week $\left.{ }^{-1}\right)$. There was a qudrática variation to the treatment with caprine biofertilizer, obtaining a maximum length of $15.6 \mathrm{~cm}$ to

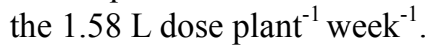

On Image 4B, to cultivate Santa Cruz 47, presented results superior to $8 \%$ on the okra fruit length compared to the Clemson Spineless 80 cultivar. These results can be justified, according to morphological aspects characteristics of each cultivar, where Santa Cruz 47 cultivar is characterized as angled fruits with 12 to $16 \mathrm{~cm}$ of length, according to Filgueira (2012), however the Clemson Spineless 80 cultivar presents straight fruits with inferior length to $15 \mathrm{~cm}$. 

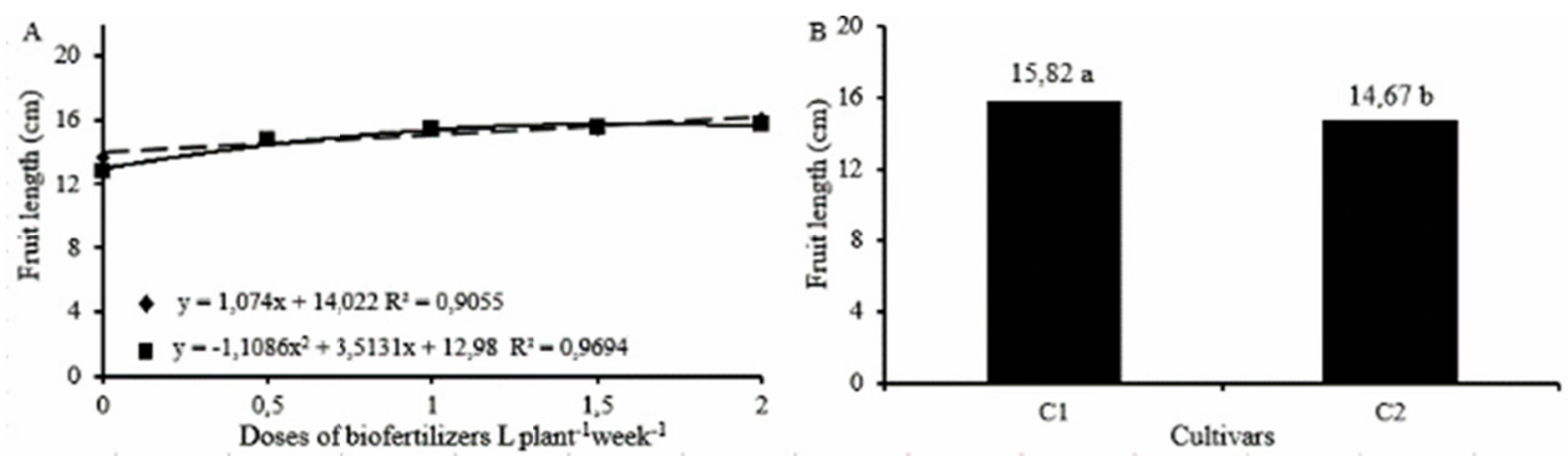

Figure 4. The okra fruit length due to the different doses of bovine ( $)$ and caprine (-) (A) biofertilizers and of two commercial cultivars (B) Santa Cruz 47 (C1) and Clemson Spineless 80 (C2)

On Image 5A, an increase on biofertilizers doses, raised the okra fruit diameter, with an unitary increase on the diameter of $1.2 \mathrm{~mm}$ per dose. There was a maximum increase of $11 \%$ on this variable, according to the $2.0 \mathrm{~L}$ plant $^{-1}$ week $^{-1}$ dose, compared to the witness dose $\left(0.0 \mathrm{~L} \mathrm{plant}^{-1}\right.$ week $\left.^{-1}\right)$.

Regarding the effects of the cultivars (Image 5B), the value of the okra fruit diameter were superior in $22.5 \%$ to the Clemson Spineless 80 cultivar, compared to Santa Cruz 47 cultivar.
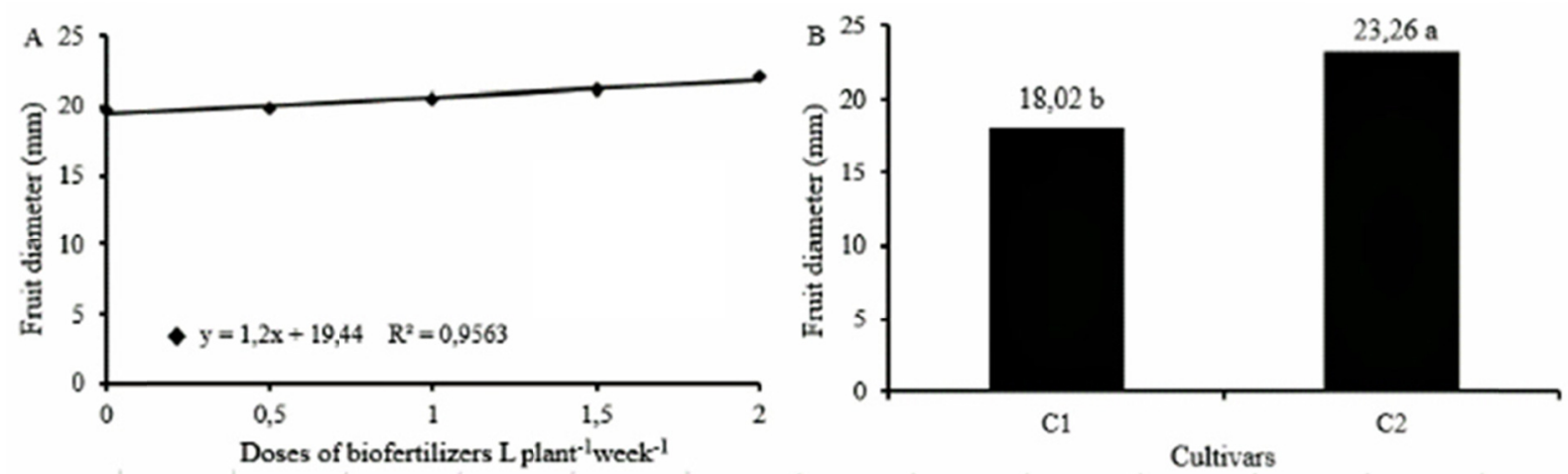

Figure 5. Okra fruit diameter due to the different doses of biofertilizer (A) and of two commercial cultivars (B) Santa Cruz 47 (C1) and Clemson Spineless 80 (C2)

From the observation of the unfolding of the interaction between doses versus types of biofertilizers, it is seen that the increase on the doses of biofertilizer raised the peel thickness of the okra fruits of the Santa Cruz 47 Cultivar (Image 6A), where the linear model was the one which adjusted best to treatment with bovine biofertilizer, with maximum increase of $29.7 \%$ compared to dose of $2.0 \mathrm{~L} \mathrm{plant}^{-1}$ week ${ }^{-1}$, and the treatment with caprine biofertilizer, there was a quadratic variation, where it was obtained a $2.07 \mathrm{~mm}$ thickness with a dose of $0.78 \mathrm{~L}_{\text {plant }}{ }^{-1}$ week ${ }^{-1}$.

In Image 6B, it is verified that the increase of biofertilizer doses provided increased thickness of the bark of okra fruits of the cultivar "Clemson Americano 80", in which the quadratic model was the best fit presenting a maximum thickness of $2.36 \mathrm{~mm}$ for the dose $1.31 \mathrm{~L}$ of bovine biofertilizer, plant ${ }^{-1}$ week $^{-1}$. As for the goats biofertilizer, linear model was best fit with maximum increase in bark thickness of $26.4 \%$, corresponding to dose 2.0 L plant ${ }^{-1}$, week ${ }^{-1}$, in comparison to the control dose $\left(0.0 \mathrm{~L} \mathrm{plant}^{-1}\right.$ week $\left.^{-1}\right)$. 

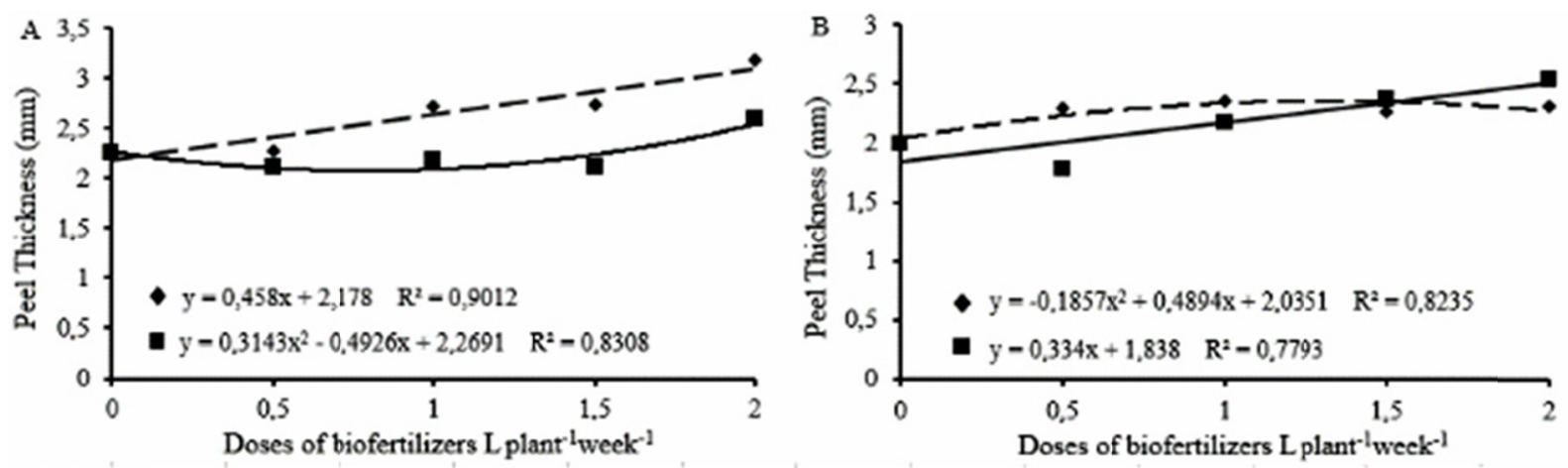

Figure 6. Okra fruit peel thickness, Santa Cruz 47 cultivar (A) and the Clemson Spineless 80 (B), submitted to different doses of bovine biofertilizer $(\bullet)$ and caprine $(\bullet)$

\section{Discussion}

The increase on the number of fruits per okra plant, on the Santa Cruz 47 cultivars (C1) and the Clemson Spineless $80(\mathrm{C} 2)$ due to the raise on the doses of biofertilizers, is possibly associated with the fact that the adequate quantities of manure gradually provide mineral elements, while that mineralization is processed from the organic matter able to supply the needs of the plant in macronutrients through the raise of the available levels $\mathrm{P}, \mathrm{K}$ and N (Santos et al., 2017).

The results are similar to the ones obtained by Oliveira et al. (2013), where it was found an increase on the number of fruits per okra plant, Santa Cruz 47 cultivar, in soils with the presence of bovine biofertilizer. Similarly, Silva et al. (2016), working with the fig culture, found an increase on the number of fruits per plant, there was a raise while the concentration of biofertilizers increased.

The manure addition provided an increase on the nutrients availability, supplying the nutritional requirements and contributing to the store of water in soil, presenting as a sustainable alternative, increasing the performance of the cultures, without causing negative effect to the environment (Borchartt et al., 2011; Pesaković et al., 2013).

The difference in average fruit mass between the two cultivars may have occurred due to the genotypic characteristics or to the acclimatization of the region (Boechatchat et al., 2010).

It is noted that the average fruit mass of cultivar "Clemson Americano 80" is situated above the commercial fruits range in okra, defined by Filgueira (2012), between 20 and $25 \mathrm{~g}$, which may indicate high nutritional contribution provided by biofertilizers in average mass of the fruits.

These results were superiors to the ones obtained by Oliveira et al. (2013), where it was found that maximum average okra fruit mass due to the supply of biofertilizer was of $18 \mathrm{~g}$, in fertilized soil with a dose of $27.5 \mathrm{tha}^{-1}$ of bovine manure.

This effect may be related to description of Cavalcante et al. (2010), where according to these authors, despite the origin, the manure, when applied in adequate doses, present positive effect on the increase of culture (Image 3 ), due to the favorable action to the physical, chemicals and biological factors of the soil.

The result shows that the maximum productivity of this work $\left(30.005 \mathrm{t} \mathrm{ha}^{-1}\right)$ is within the national average, between 20 and $40 \mathrm{~T} \mathrm{ha}^{-1}$, as Filgueira (2012). A similar result to this study was registered by Oliveira et al. (2013), in which the dose of $31 \mathrm{~T} \mathrm{ha}^{-1}$ of bovine manure was responsible for the maximum productivity of $22 \mathrm{~T}$ $\mathrm{ha}^{-1}$ of okra. Silva et al. (2016), in fig plants, obtained similar results, in which the use of bovine biofertilizer provided an increase in crop productivity.

The use of organic fertilizers becomes a viable and cheaper alternative in the organic production to the small and medium region producers, once the fertility of the soils and the quality of the fruits improve (Silva et al., 2016).

Particular attention is drawn to the studies using organic sources to fruit length variable in plant specie, there are still no reports. However, similar to this study Santos et al. (2014a), obtained an increase on the length of the melon, due to the raise on the doses of biofertilizer. Likewise, Santos et al. (2014b), working with the culture of banana, found that the fruit length raised with the increase on the doses of biofertilizer. 
The increase of the okra fruits diameter from increasing biofertilizer doses may be related to the availability of essential nutrients to the plants, which are provided by the biofertilizers (Viana et al., 2013), promoting greater growth of the fruit.

Lima et al. (2018) found that the increase on the doses of bovine biofertilizer advanced the increase on the strawberry fruit diameter, in the dose of $500 \mathrm{~mL} \mathrm{per} \mathrm{week}^{-1}$ plant $^{-1}$, was responsible for the maximum diameter of $21.41 \mathrm{~mm}$. Opposite results were found by Silva et al. (2016), where it was not found significant effect of the use of biofertilizer on the fig fruit diameter.

Therefore, it can be verified that there are differences between the cultivars (Image 5B, that possibly is related to the genetic improvement, existing distinct morphological characteristics in the cultivars, consequently affecting the fruits attributes).

The increase in the thickness of the bark due to the increase of the doses of bovine and goat biofertilizer for the cultivars "Santa Cruz 47" and "Clemson Americano 80" can be justified by the fact that the potassium present in the biofertilizer increases the $\mathrm{CO}_{2}$ fixation and promotes the transport of photoassimilates for the fruits, justifying the improvement in fruit quality (Meurer et al., 2018).

The superiority of the Clemson Spineless 80 cultivar compared to the the Santa Cruz 47 cultivar, can also be related to the physiological capacity of the culture in transport the nutrients in higher quantity to the phytomass.

Similar tendency was found by Santos et al. (2014), confirmed that the raise on the doses of biofertilizer, there was an increase on thickness of the mesocarp of the melon fruit. Rocha et al. (2013), testing the bovine biofertilizer (pure and enriched), also shows an increase on the peel thickness of the yellow passion fruit.

\section{Conclusions}

The raise on the doses of bovine and caprine biofertilizers favor the yield of fruits per okra plant and the fruit peel thickness, on the Santa Cruz 47 and Clemson Spineless 80 cultivar.

The bovine biofertilizer was more efficient to the raise on the average okra fruits mass. The increase on the doses contributed to higher fruit lengths.

The Santa Cruz 47 cultivar has superior value in fruit length, however the Clemson Spineless 80 cultivar, has higher levels in the variables: average mass and fruit diameter.

\section{References}

Boechatchat, C. L., Martins Teixeira, A. R. E. T. U. S. A., Vieira Da Costa, A. S., \& Souza Barbosa, A. P. D. (2010). Influência de substratos associados à adubação mineral sobre o crescimento inicial de duas cultivares de maracujazeiro-amarelo. Revista Caatinga, 23(3).

Borchartt, L., Silva, I. F., Santana, E. O., Souza, C., \& Ferreira, L. E. (2011). Adubação orgânica da batata com esterco bovino no município de Esperança-PB. Revista Ciência Agronômica, 42(2), 482-487.

Cavalcante, L. F., Vieira, M. Da S., Santos, A. F. Dos, Oliveira, W. M. De, Nascimento, J. A. M. Do. (2010). Água salina e esterco bovino líquido na formação de mudas de goiabeira cultivar Paluma. Revista Brasileira de Fruticultura, 32(1), 251-261.

EMBRAPA (Empresa Brasileira de Pesquisa Agropecuária). (2018). Sistema brasileiro de classificação de solos (5th ed., p. 590). Brasília, DF: Embrapa.

Filgueira, F. A. R. (2012). Novo Manual de Olericultura. Agrotecnologia moderna na produção e comercialização de hortaliças (3rd ed., p. 421) Viçosa, MG: UFV.

IBGE (Instituto Brasileiro de Geografia e Estatística). (2017). Sistema IBGE de Recuperação Automática-SIDRA. Retrieved from https://sidra.ibge.gov.br/tabela/6619\#resultado

Köppen, W. (1918). Com un estudio de los climas de la tierra. Climatologia (p. 478). Mexico: Fondo de Cultura Economica.

Lima, F. A., Viana, T. V. A., Sousa, G. G., Correia, L. F. M., \& Azevedo, B. M. (2018). Yield of strawberry crops under different irrigation levels and biofertilizer doses. Revista Ciência Agronômica, 49(3), 381-388. https://doi.org/10.5935/1806-6690.20180043

Malavolta, E., Vitti, G. C., \& Oliveira, S. A. (1997). Avaliação do estado nutricional das plantas: Princípios e aplicações (p. 201). Piracicaba: POTAFOS.

Meurer, E. J., et al. (2018). XII-POTÁSSIO. In M. S. Fernandes, S. R. Souza, \& L. A. Santos (Eds.), Nutrição mineral de plantas (2nd ed., p. 670). Viçosa, MG: SBCS. 
Oliveira, A. P., Oliveira, A. N., Silva, O. P. R., Pinheiro, S. M., \& Gomes Neto, A. D. (2013). Rendimento Do Quiabo Adubado Com Esterco Bovino e Biofertilizante. Semina: Ciências Agrárias, 34(6), 2629-2636. https://doi.org/10.5433/1679-0359.2013v34n6p2629

Oliveira, A. P., Silva, O. P. R., Silva, J. A., Silva, D. F., Ferreira, D. T. A., \& Pinheiro, S. M. G. (2014). Rendimento de maxixe em solo arenoso em função de doses de esterco bovino e biofertilizante. Revista Brasileira de Engenharia Agrícola e Ambiental, 18(11). https://doi.org/10.1590/1807-1929/agriambi. v18n11p1130-1135

Penteado, S. R. (2007). Adubação Orgânica: Compostos orgânicos e biofertilizantes (2nd ed., p. 162). Campinas: Edição do Autor.

Pesakovic, M., Stajic, K. S., Slobodan, M., \& Olga, M. (2013). Biofertilizer affecting yield related characteristics of strawberry (Fragaria $\times$ ananassa Duch.) and soil micro-organisms. Scientia Horticulturae, 150, $238-243$. https://doi.org/10.17221/180/2014-HORTSCI

Rocha, L. F., Cunha, M. C., Santos, E. M., Lima, F. N., Mancin, A. C., \& Cavalcante, I, H. L. (2013). Biofertilizante, calagem e adubação com NK nas características físicas e químicas de frutos de maracujazeiro-amarelo. Revista Brasileira de Ciências Agrárias, 8(4), 555-562. https://doi.org/ 10.5039/agraria.v8i4a2939

Santos, A. P. G., Viana, T. V. A., Sousa, G. G., Ó, L. M. G., Azevedo, B. M., \& Santos, A. M. (2014a). Produtividade e qualidade de frutos do meloeiro em função de tipos e doses de biofertilizantes. Horticultura Brasileira, 32(4), 409-416. https://doi.org/10.1590/S0102-053620140000400007

Santos, J. G. R., Andrade, R., Galdino, P. O., Linhares, A. S. F., Maia, P. M. E., \& Lima, A. S. (2014b). Qualidade da produção da bananeira Nanicão em função do uso de biofertilizantes. Revista Brasileira de Engenharia Agrícola e Ambiental, 18(4), 387-393.

Santos, E. O., Viana, T. V. A., Sousa, G. G., Carvalho, A. C. P. P., \& Azevedo, B. M. (2017). Biomass accumulation and nutrition in micropropagated plants of the banana 'prata catarina' under biofertilisers. Revista Caatinga, 30(4), 901-911.

Sousa, G. G., Viana, T. V. A., Braga, E. S., Azevedo, B. M., Marinho, A. B., \& Borges, F. R. (2013). Fertirrigação com biofertilizante bovino: Efeitos no crescimento, trocas gasosas e na produtividade do pinhão-manso. Revista Brasileira de Ciências Agrárias, 8(3), 503-509. http://doi.org/10.5039/agraria. v8i3a 2288

Silva, F. L., Viana, T. V. A., Sousa, G. G., Costa, S. C., \& Azevedo, B. M. (2016). Yield of common fig fertigated with bovine biofertilizer in thesemiarid region of ceará. Revista Caatinga, 29(2), 425-434.

Viana, T. V. De A., Santos, A. P. G., Sousa, G. G., Pinheiro Neto, L., Azevedo, B. M., \& Aquino, B. F. (2013). Trocas gasosas e teores foliares de NPK em meloeiro adubado com biofertilizantes. Agrária-Revista Brasileira de Ciências Agrárias, 8(4), 595-601.

\section{Copyrights}

Copyright for this article is retained by the author(s), with first publication rights granted to the journal.

This is an open-access article distributed under the terms and conditions of the Creative Commons Attribution license (http://creativecommons.org/licenses/by/4.0/). 